\title{
Retinal thickness assessed by optical coherence tomography (OCT) in pseudophakic macular edema
}

\author{
Espessura retiniana medida pela tomogra fia de coerência óptica (OCT) \\ noedema maculardopseudofácico
}

\author{
Maria Teresa Brizzi Chizzoti Bonanomi ${ }^{1}$ \\ André Gustavo Bombana Nicoletti ${ }^{2}$ \\ Pedro Carlos Carricondo ${ }^{3}$ \\ Flávio Buzalaf ${ }^{4}$ \\ Newton Kara-José Jr.5 \\ André Marcelo Vieira Gomes ${ }^{6}$ \\ Yoshitaka Nakashima ${ }^{7}$
}

Hospital das Clínicas, Department of Ophthalmology Universidade de São Paulo - São Paulo (SP) - Brasil.

${ }^{1}$ Doctor in Ophthalmology, Retina Service. Hospital das Clínicas, Department of Ophthalmology Universidade de São Paulo - USP - São Paulo (SP) - Brasil.

2 Doctor in Ophthalmology, Retina Service. Hospital das Clínicas, Department of Ophthalmology USP - São Paulo (SP) - Brasil.

${ }^{3}$ Doctor in Ophthalmology, Retina Service. Hospital das Clínicas, Department of Ophthalmology USP - São Paulo (SP) - Brasil.

${ }^{4}$ Doctor in Ophthalmology, Retina Service. Hospital das Clínicas, Department of Ophthalmology USP - São Paulo (SP) - Brasil.

${ }^{5}$ Doctor in Ophthalmology, Retina Service. Hospital das Clínicas, Department of Ophthalmology USP - São Paulo (SP) - Brasil.

${ }^{6}$ Doctor in Ophthalmology, Retina Service. Hospital das Clínicas, Department of Ophthalmology USP - São Paulo (SP) - Brasil.

Doctor in Ophthalmology, Retina Service. Hospital das Clínicas, Department of Ophthalmology USP - São Paulo (SP) - Brasil.

Address for correspondence: Maria Teresa Bonanomi. Rua José Bonifácio, 87 - Jacareí (SP) CEP 12327-190

E-mail: mtbonanomi@uol.com.br

Recebido para publicação em 18.09.2005

Versão revisada recebida em 25.04.2006

Aprovação em 28.04.2006

Research sources: Pub Med, SciElo and LILACS.

\begin{tabular}{l} 
ABSTRACT \\
\hline Purpose: To evaluate the usefulness of the optical coherence tomography \\
(OCT) retinal map in angiographic pseudophakic macularedema (ACME). \\
Methods: This is a prospective analysis of a group of 36 pseudophakic \\
eyes at the fifth postoperative week, submitted to optical coherence \\
tomography 2 macular map and fluorescein angiography on the same day \\
and, a control group of twenty-two $20 / 20$ vision eyes with a minimum $6-$ \\
month postoperative period, submitted to optical coherence tomography \\
2 macular map only. Exclusion criteria were diabetes, any macular patho- \\
logy and unreadable optical coherence tomography or angiogram. The \\
angiograms were divided into three groups according to the edema \\
intensity: Group I: level 0 (absence of angiographic pseudophakic \\
macular edema); group II: levels 1 and 2 (incomplete and complete \\
perifoveal angiographic pseudophakic macular edema respectively) and \\
group III: levels 3 and 4 (up to one disc diameter and greater than one disc \\
diameter angiographic pseudophakic macular edema area respectively). \\
The nine zones of the optical coherence tomography macular map were \\
compared between the control and the three subgroups of the study \\
group and, between group I and groups II and III. Results: Among the \\
36 eyes, 23 (64\%) were classified as group I, 10 ( $28 \%$ ) as group II and three \\
( $8 \%$ ) as group III. The mean thickness of the fovea zone was $185 \pm 15 \mu m$ \\
for the control group, $189 \pm 24 \mu$ for group I, $213 \pm 33 \mu$ for group II and \\
$455 \pm 38 \mu$ for group III. Significant differences: between group III and \\
the control or group I for all zones (p<0.01) and, between group II and \\
control or group I for the fovea and temporal inner zones (p<0.05). \\
Conclusion: The optical coherence tomography retinal map is useful in \\
angiographic pseudophakic macular edema diagnosis.
\end{tabular}

Keywords: Cataract; Macular edema, cystoid/diagnosis; Fluorescein angiography; Tomography, optical coherence; Retina/pathology

\section{INTRODUCTION}

Cataract is the main cause of blindness among the adult population ${ }^{(1)}$. It is estimated that, in India alone, 3.8 million people become blind from cataract every year ${ }^{(2)}$. The rate of cataract surgery has been reported to increase from 1.2 to 7.2 in 1,000 inhabitants per year, in a period of eight years. This is explained not only by the population lifespan but is mainly due to earlier surgical procedures ${ }^{(3)}$. Macular edema in pseudophakic eyes continues to cause disappointing visual results in uneventful surgeries, despite the decrease in complication rate associated with the current surgical techniques. 
The angiographic macular edema (ACME), detected by the fifth post-operative week is reported in $24 \%{ }^{(4)}$ of eyes with posterior chamber lens implants and, as many as 50\% using several cataract extraction techniques ${ }^{(5)}$. Routinely, macular edema has been diagnosed by slit lamp biomicroscopy and fluorescein angiography ${ }^{(4-6)}$. Biomicroscopy of the macula is a difficult, subjective and often an inconclusive examination of recently operated eyes due to photophobia and light diffraction in the eye or in the intraocular lens. Fluorescein angiography is an invasive test and may not be conclusive in $15 \%$ of cases in the cataract postoperative follow-up ${ }^{(6)}$.

Optical coherence tomography (OCT) is an interferometric method, which provides optical cross-sectional images of the eye $^{(7)}$. The macular map program (Humphrey Instruments, Inc. San Leandro California) analyzes six, 6mm scans radiated through the fovea and provides an average retinal thickness map in nine regions of the macula. OCT has been used to study macular thickness in diabetes ${ }^{(8-10)}$, uveitis ${ }^{(11)}$ and after cataract surgeries ${ }^{(12-15)}$. Macular thickening as measured by the OCT mapping software has recently been shown to correlate with visual loss in pseudophakia ${ }^{(15)}$. The purpose of this study is to assess the macular thickness by the OCT retinal map software at the various ACME levels.

\section{METHODS}

This is a prospective cross-sectional trial, conducted among a study group of 50 pseudophakic eyes in 48 patients and a control group of 30 eyes of 25 patients. In the study group, surgery was performed by a second- or a third-year medical resident on all patients and the three-piece polymethylmethacrylate (PMMA) lens with 6-mm optic zone intraocular lenses (LIO) were implanted. All eyes were submitted to the OCT 2 retinal map using the internal fixation target between the $4^{\text {th }}$ and the $6^{\text {th }}$ postoperative week. Patients who were unable to see the fixation target were not included. Those patients with reliable OCT maps and at least five meridians without imperfections, were submitted to fluorescein angiography on the same day. Fourteen eyes of fourteen patients showed substandard angiograms and were excluded. The control group comprised thirty 20/20 vision pseudophakic eyes of 25 patients, who received the same lens as the study group, and had a minimum postoperative period of six months. The eyes in the control group were presumed to have a normal macula and were submitted to the OCT 2 macular map only. In this group, eight eyes of seven patients were excluded due to the poor OCT quality. In both groups, a posterior pole biomicroscopy was performed to rule out signs of macular pathology like blood, anomalous pigmentation or drusen. The exclusion criteria were: diabetes, any eye disease and unreadable OCT or angiogram. The final participants were: 36 eyes of 34 patients (study group) and 22 eyes of 18 patients (control group). The angiograms were classified and divided into three groups by reading one of the latest pictures of the examination (roughly 5 to 10 minutes) $^{(16)}$. Group I: level 0 (absence of ACME); group II: levels 1 and 2 (incomplete and complete perifoveal ACME respectively) and group III: levels 3 and 4 (up to one disc diameter and greater than one disc diameter ACME area respectively). The OCT macular map is divided into nine zones that correspond to the Early Treatment Diabetic Retinopathy Study Research - ETDRS ${ }^{(17)}$ regions: fovea within $1000 \mu \mathrm{m}$ centered on the fixation point; internal peripheral ring, the circular band from the central $1000 \mu \mathrm{m}$ to $3000 \mu \mathrm{m}$, divided into upper, lower, temporal, and nasal and; external peripheral ring from $3000 \mu \mathrm{m}$ up to $6000 \mu \mathrm{m}$ and the same subdivisions (Figure 1); therefore, fovea thickness relates to the mean of the six spoke meridians inside $1000 \mu \mathrm{m}$ centered on the foveola. The nine OCT zones were compared between the three subgroups of the study group and the control group and, between group I and groups II and III. To enable the data analysis, the Kruskal-Wallis method and Dunn's comparison was used. Hospital das Clinicas's Institutional Ethics Committee's approval was obtained.

\section{RESULTS}

Among the 34 patients in the study group, 19 patients were female and 15 were male ranging in age (mean \pm standard deviation) from 29 to $79(66 \pm 10)$ years. Among the 36 eyes, 13 (36\%) showed ACME with the subgroup classification as follows: 23 (64\%) in group I, $10(28 \%)$ in group II and $3(8 \%)$ in group III. In the control group, 8 patients were female and 10 were male with ages ranging from 28 to $79(64 \pm 11)$ years. The visual acuity (refraction) ranged from 20/20 to 20/60 (3.50 spherical and 5.00 cylindrical) in group I, from $20 / 20$ to $20 / 100$ (2.00 spherical and 5.00 cylindrical) in group II and, from 20/60 to $20 / 80$ (2.00 spherical and 1.00 cylindrical) in group III. The retinal thickness for fovea ranged from 156 to $208 \mu \mathrm{m}$ $(185 \pm 15 \mu \mathrm{m})$ for the control group; in the study group it ranged from 153 to $232 \mu \mathrm{m}(189 \pm 24 \mu \mathrm{m})$ for group I, from 163 to $260 \mu \mathrm{m}$ $(213 \pm 33 \mu \mathrm{m})$ for group II and from 419 to $494 \mu \mathrm{m}(455 \pm 38 \mu \mathrm{m})$ for group III. The mean retinal thickness of the nine zones of the OCT map and the significance levels, considering all samples, are displayed in table 1. When compared to group I or to the control group, group III showed highly significant thicker retina for all zones $(\mathrm{p}<0.01)$, in particular for the fovea and inner nasal regions $(\mathrm{p}<0.001)$. When compared to group I or to the control group, group II showed significant thicker retina in fovea and inner temporal regions $(\mathrm{p}<0.05)$. The individual values in decreasing order for the fovea zone in the eyes with ACME are $260 \mu \mathrm{m}, 256 \mu \mathrm{m}, 237 \mu \mathrm{m}, 233 \mu \mathrm{m}, 215 \mu \mathrm{m}$, $212 \mu \mathrm{m}, 194 \mu \mathrm{m}, 187 \mu \mathrm{m}, 174 \mu \mathrm{m}$ and $163 \mu \mathrm{m}$, in group II and, $494 \mu \mathrm{m}, 453 \mu \mathrm{m}$ and $419 \mu \mathrm{m}$ in group III.

\section{DISCUSSION}

Although only a small percentage of eyes were reported to show a substantial reduction of visual acuity due to pseudo- 

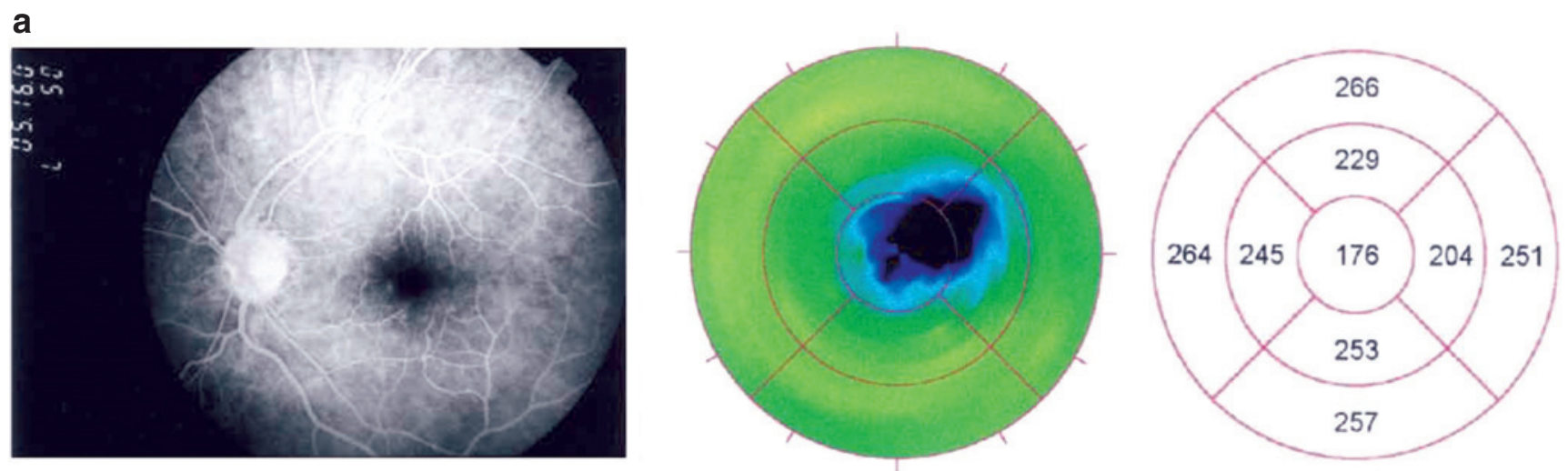

b
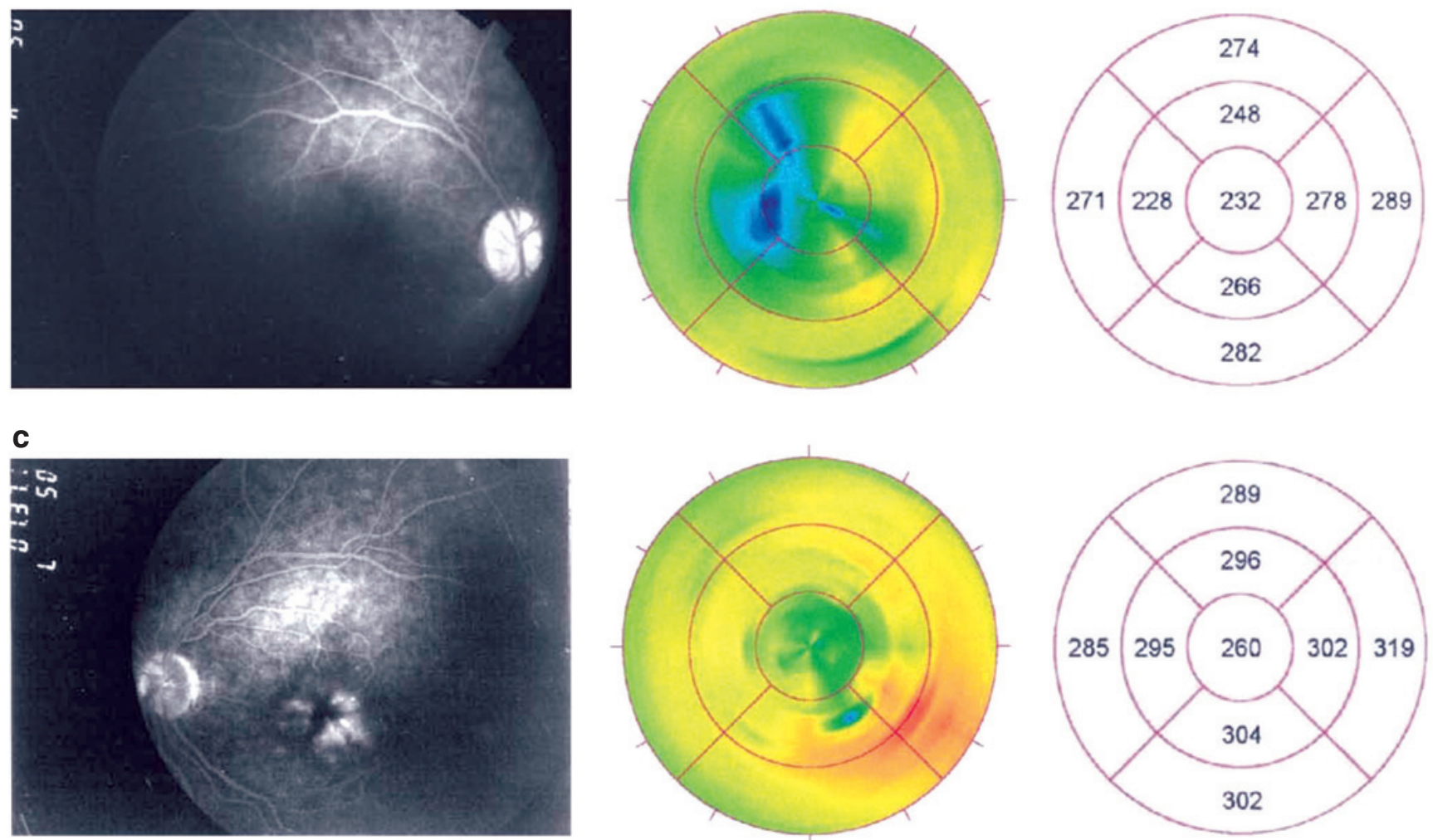

\section{d}
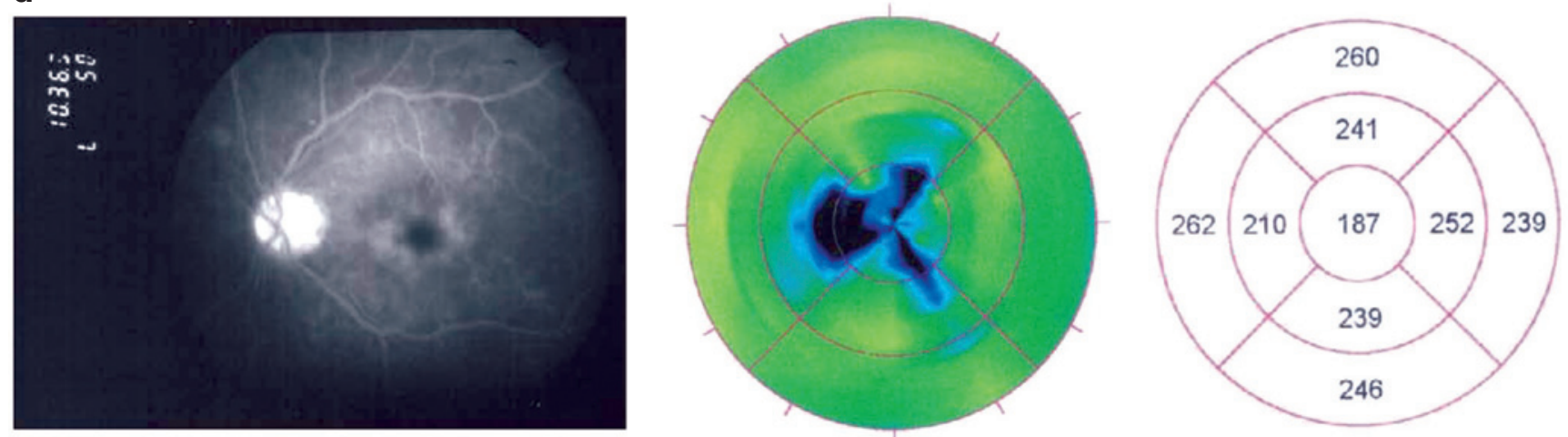

Figure 1 - Late angiogram's frame and corresponding retinal map diagram. Level zero ACME (group I) - a: male, 58 years old, 20/40 vision, retinal thickness at the fovea: $176 \mu \mathrm{m}$; b: male, 51 years old, 20/20 vision, retinal thickness at the fovea: $232 \mu \mathrm{m}$. Level 1 and 2 ACME (group II) - c: male, 64 years old, 20/20 vision, retinal thickness at the fovea: $260 \mu \mathrm{m}$; d: female, 77 years old, 20/20 vision, retinal thickness at the fovea: $187 \mu \mathrm{m}$. 


\begin{tabular}{|c|c|c|c|c|c|}
\hline \multirow[b]{2}{*}{ Zone } & \multicolumn{5}{|c|}{ Retinal thickness in micron (mean \pm standard deviation) } \\
\hline & Control $(n=22)$ & Group I $(n=23)$ & Group II $(n=10)$ & Group III $(n=3)$ & $\mathbf{p}$ \\
\hline Fovea & $185 \pm 15$ & $189 \pm 24$ & $213 \pm 33^{\ddagger}$ & $455 \pm 38^{*}$ & 0.0032 \\
\hline Superior inner & $247 \pm 17$ & $242 \pm 21$ & $257 \pm 21$ & $367 \pm 21^{*}$ & 0.010 \\
\hline Inferior inner & $246 \pm 20$ & $242 \pm 17$ & $253 \pm 32$ & $412 \pm 58^{*}$ & 0.027 \\
\hline Temporal inner & $223 \pm 19$ & $224 \pm 24$ & $245 \pm 26^{\ddagger}$ & $444 \pm 86^{*}$ & 0.0052 \\
\hline Nasal inner & $247 \pm 17$ & $234 \pm 23$ & $254 \pm 43$ & $374 \pm 33^{*}$ & 0.0050 \\
\hline Superior outer & $252 \pm 15$ & $257 \pm 15$ & $260 \pm 19$ & $294 \pm 22^{*}$ & 0.018 \\
\hline Inferior outer & $254 \pm 14$ & $252 \pm 17$ & $263 \pm 21$ & $322 \pm 55^{\star}$ & 0.039 \\
\hline Temporal outer & $244 \pm 15$ & $240 \pm 22$ & $255 \pm 32$ & $404 \pm 122^{*}$ & 0.019 \\
\hline Nasal outer & $261 \pm 12$ & $259 \pm 15$ & $266 \pm 20$ & $312 \pm 33^{*}$ & 0.017 \\
\hline
\end{tabular}

phakic macular edema ${ }^{(4,6,16)}$, this entity still continues to be troublesome for doctors and their patients after uneventful cataract extraction. This study was conducted to evaluate the usefulness of the OCT retinal map in ACME diagnosis.

OCT is currently the most precise technique to measure retinal thickness in vivo. In one study, using manual OCT measurement of three horizontal and one vertical $2.8 \mathrm{~mm}$ lines through the fovea, analyzing the data with the angiograms of 153 diabetic macular edema patients and comparing them with the 30 control subjects, the authors found a sensitivity of $89 \%$ and specificity of $96 \%$ for detecting clinically significant macular edema. The optimum variability coefficient between the measurements was reported to range from 2.3 to $3.3 \%$ for the control group and from 1.4 to $2.4 \%$ for diabetic patients ${ }^{(9)}$. Other authors, assessing through OCT the foveal thickness in 21 healthy eyes and nine having a macular edema, found a variability coefficient in the same patient of $10 \%$ in the control group and $15 \%$ among diabetics. The measurements were compared to those conducted using the Retina Thickness Analyser (RTA). Both methods produced reproducible values but, since the RTA showed a high number of falsely elevated measurements, it was concluded that the reliability of OCT was better ${ }^{(18)}$. In 1998 a macular map software was developed, allowing a bidimensional mapping of the macula ${ }^{(8)}$. In this protocol, six $6 \mathrm{~mm}$ long radiated lines, crossing each other at the fovea center, in a spoken pattern provide automatically the means for the nine macular ETDRS zones (mean of six lines for the fovea and mean of three lines in the peripheral inner and outer zones). The study has assessed 182 eyes with diabetic retinopathy, 55 eyes without retinopathy in diabetic patients and 73 eyes of healthy volunteers. It was found that the average reproducibility of the central fovea thickness was 11 $\mu \mathrm{m}$ in healthy patients and approximately $20 \mu \mathrm{m}$ in diabetic patients. Also by this method, 10 eyes of healthy individuals and 10 eyes of diabetic subjects were studied, and the conclusion was that the interobserver, intraobserver and intervisitor reproducibility was excellent. A repeatability coefficient of less than $7 \mu \mathrm{m}$ for healthy and $21 \mu \mathrm{m}$ for diabetic subjects was found and, an intraclass correlation coefficient greater than
0.89 for healthy and 0.98 for diabetic subjects. The measurement variances were small in both healthy and diabetic subjects with reproducibilities of $\pm 5 \%$ and $\pm 6 \%$, respectively ${ }^{(10)}$.

We faced many difficulties in performing the OCT retinal map by the 5 th postoperative week. Though using the near infrared light, elderly people felt uneasy during the 6-scan records. Most of them were unwilling to repeat the examination and therefore, all retinal maps with at least five acceptable scan lines were included in this study. When taking the OCT scans, we noticed that the presence of an intraocular lens hampered the focus and, a double line was often visible in the retinographic image (Figure 2). This seems to signify either none or little damage in the scan reliability since it was shown that the presence of the intraocular lens does not influence retinal thickness assessment ${ }^{(13)}$ and, even in the presence of visually significant posterior capsule opacification, OCT is a reliable method to measure the foveal thickness ${ }^{(14)}$.

Studies in pseudophakic eyes are less numerous than in diabetic patients. In one of these reports, comparing retros-

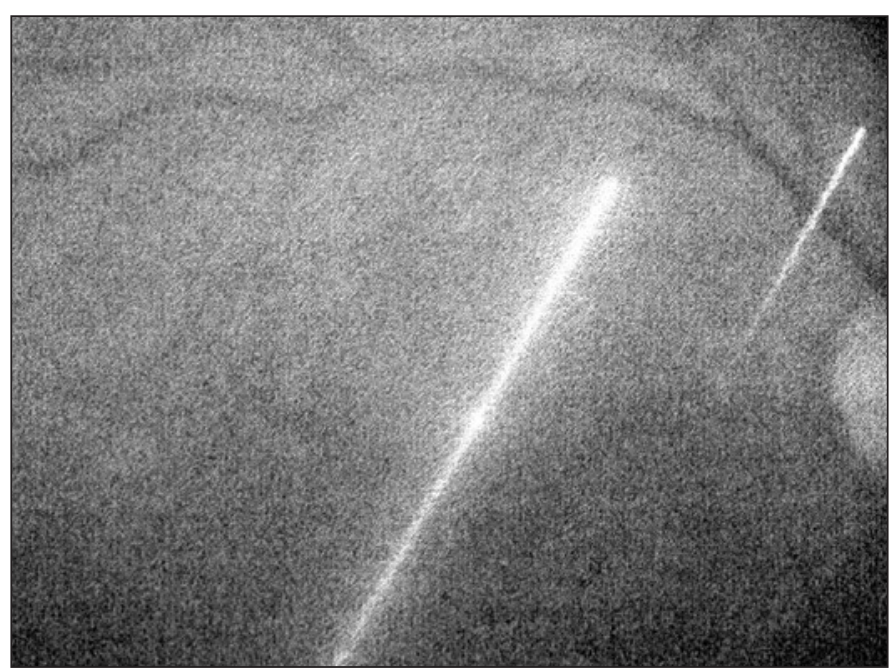

Figure 2 - Image from the video camera showing a double scan line. This is the right eye of a male, 49-year-old patient with the refraction: $-1.00-0.50$ axis $35^{\circ}(20 / 20)$. 
pectively the preoperative retinal thickness at the foveal center with four postoperative periods, considering the scanograms to be abnormal when $15 \mu \mathrm{m}$ thicker than the preoperative value, the macula was considered thicker in 11 out of 41 eyes $(27 \%)$, less than our angiographic findings $(36 \%)^{(12)}$.

In the present study, the foveal thickness for the control group and for group I was $185 \pm 15 \mu \mathrm{m}$ and $189 \pm 24 \mu \mathrm{m}$ in the fovea zone respectively, which is about $10 \mu \mathrm{m}$ more than what was reported for eyes with no intraocular implant: $174 \pm 18 \mu \mathrm{m}^{(8)}$ and of $177 \pm 19 \mu \mathrm{m}$ to $179 \pm 19 \mu \mathrm{m}^{(10)}$. This difference is inside the average reproducibility of the method ${ }^{(8,10)}$. Since the fovea thickness is an efficient indicator of the degree of diabetic edema on the OCT map ${ }^{(8,10)}$, it may be presumed that the same is true for ACME, which is a perifoveal disease. The ACMEs of group III, which are more easily diagnosed biomicroscopically, showed a high statistical difference in the retinal thickness at the fovea $(455 \pm 38 \mu \mathrm{m})$ when compared to group I and to the control group. In table 1 we can see that the highest significance level in thickness was between group III and the control group for the fovea and, between group III and group I for the inner nasal zone $(\mathrm{p}<0.001)$. All other zones of group III eyes showed less significant difference from the control and group I eyes $(\mathrm{p}<0.01)$. Group II ACME, which is the most difficult to diagnose by slit lamp biomicroscopy, showed statistically significant difference from the control group or group I in fovea and inner temporal zones $(\mathrm{p}<0.05)$. When individual fovea values in these groups were looked at, a maximum measurement of $232 \mu \mathrm{m}$ in group I and the range from 163 to $260 \mu \mathrm{m}$ for group II were found. Considering that the variation for the method is about $10 \mu \mathrm{m}^{(7-8,10)}$, it may be difficult to differentiate edema and no edema eyes in isolated cases. Should a fovea thickness of over $232 \mu \mathrm{m}$ on the OCT macular map call the hypothesis of ACME among patients having this type of intraocular lens? Due to the smallness of our sample, a value beyond which a retinal thickening could be suspected can not be established. Figure 1 illustrates the overlap which may occur in individual cases between group I and group II eyes.

\section{CONCLUSION}

In conclusion, using the OCT 2 retinal map program, levels 3 and 4 ACME eyes (group III) showed a thicker retina than the control and no edema eyes in the nine studied zones. For levels 1 and 2 ACME eyes (group II) the fovea and temporal inner zones showed a thicker retina than control and no edema eyes. The OCT 2 retinal map is a reliable method to assess ACME. The fast OCT 3 map, simultaneously obtaining all six images, may prove to be better for the diagnosis of this entity.

\section{RESUMO}

Objetivo: Medir a espessura retiniana pela tomografia de coerência óptica (OCT) no edema macular angiográfico do pseudofácico (ACME). Métodos: Trabalho prospectivo composto de um grupo de estudo com 36 olhos pseudofácicos, entre a $4^{\underline{a}}$ e a $6^{\underline{a}}$ semana de pós-operatório, submetidos ao mapa macular com a tomografia de coerência óptica $2 \mathrm{e}$ à angiofluoresceinografia no mesmo dia e, um grupo controle com 22 olhos pseudofácicos com visão igual a 20/20 e no mínimo 6 meses de pós-operatório, submetidos apenas ao mapa macular com o tomografia de coerência óptica 2. Os critérios de exclusão foram diabetes e maculopatias e exames de qualidade insuficiente para análise. Os angiogramas foram divididos em 3 grupos segundo a intensidade do edema: Grupo I: nível 0 (ausência de edema macular angiográfico do pseudofácico); grupo II: níveis 1 e 2 (edema macular angiográfico do pseudofácico perifoveal incompleto e completo) e grupo III: níveis 3 e 4 (edema macular angiográfico do pseudofácico até um e maior que um diâmetro papilar de área). As nove zonas do mapa macular da tomografia de coerência óptica foram comparadas entre o controle os três subgrupos do grupo de estudo e, entre o grupo I e os grupos II e III. Resultados: Dos 36 olhos do grupo de estudo, 23 (64\%) foram classificados como grupo I, 10 (28\%) como grupo II e 3 (8\%) como grupo III. A espessura para a zona fóvea foi de $185 \pm 15 \mu \mathrm{m}$ no grupo controle, de $189 \pm 24 \mu \mathrm{m}$ no grupo I, de $213 \pm 33 \mu \mathrm{m}$ no grupo II e de $455 \pm$ $38 \mu \mathrm{m}$ no grupo III. Diferenças significativas para esta região foram observadas entre o grupo controle ou grupo I e o grupo III para todas as zonas $(\mathrm{p}<0,01)$ e, entre o grupo I e o grupo II para a zona fóvea e a temporal interna $(\mathrm{p}<0,05)$. Conclusão: $\mathrm{O}$ programa de mapa macular da tomografia de coerência óptica 2 é útil para o diagnóstico de edema macular angiográfico do pseudofácico.

Descritores: Catarata; Edema macular cistóide/ diagnóstico; Angiofluoresceinografia; Tomografia de coerência óptica; Retina/patologia

\section{REFERENCES}

1. Eduardo Leite Arieta C, Nicolini Delgado AM, Jose NK, Temporini ER, Alves MR, de Carvalho Moreira Filho D. Refractive errors and cataract as causes of visual impairment in Brazil. Ophthalmic Epidemiol. 2003;10(1):15-22.

2. Minassian DC, Mehra V. 3.8 million blinded by cataract each year: projections from the first epidemiological study of incidence of cataract blindness in India. Br J Ophthalmol. 1990;74(6):341-3. Comment in: Br J Ophthalmol. 1990;74 (6):324.

3. Leinonen J, Laatikainen L. Changes in visual acuity of patients undergoing cataract surgery during the last two decades. Acta Ophthalmol Scand. 2002;80 (5):506-11.

4. Wright PL, Wilkinson CP, Balyeat HD, Popham J, Reinke M. Angiographic cystoid macular edema after posterior chamber lens implantation. Arch Ophthalmol. 1988;106(6):740-4.

5. Stark WJ Jr, Maumenee AE, Fagadau W, Datiles M, Baker CC, Worthen D, Klein P, Auer C. Cystoid macular edema in pseudophakia. Surv Ophthalmol. 1984;28Suppl:442-51.

6. Hitchings RA. Aphakic macular oedema: a two-year follow-up study. Br J Ophthalmol. 1977;61(10):628-30.

7. Hee MR, Izatt JA, Swanson EA, Huang D, Shuman JS, Lin CP, et al. Optical coherence tomography of the human retina. Arch Ophthalmol 1995;113(3):325-32.

8. Hee MR, Puliafito CA, Duker JS, Reichel E, Coker JG, Wilkins JR, et al. Topography of diabetic macular edema with optical coherence tomography. Ophthalmology 1998;105(2):360-70. 
9. Goebel W, Kretzchmar-Gross T. Retinal thickness in diabetic retinopathy: a study using optical coherence tomography (OCT). Retina. 2002;22(6):759-67.

10. Massin P, Vicaut E, Haouchine B, Erginay A, Paques M, Gaudric A. Reproducibility of retinal mapping using optical coherence tomography. Arch Ophthalmol. 2001;119(8):1135-42.

11. Antcliff RJ, Stanford MR, Chauhan DS, Graham EM, Spalton DJ, Shiling JS, et al. Comparison between optical coherence tomography and fundus fluorescein angiography for the detection of cystoid macular edema in patients with uveitis. Ophthalmology 2000;107(3):593-9.

12. Sourdille P, Santiago PY. Optical coherence tomography of macular thickness after cataract surgery. J Cataract Refract Surg. 1999;25(2):256-61.

13. Grewing R, Becker H. Retinal thickness immediately after cataract surgery measured by optical coherence tomography. Ophthalmic Surg Lasers. 2000;31 (3):215-7.
14. Hougaard JL, Wang M, Sander B, Larsen M. Effects of pseudophakic lens capsule opacification on optical coherence tomography of the macula. Curr Eye Res. 2001;23(6):415-21.

15. Catier A, Tadayoni R, Paques M, Erginay A, Haouchine B, Gaudric A, et al. Characterization of macular edema from various etiologies by optical coherence tomography. Am J Ophthalmol. 2005;140(2):200-6.

16. Yannuzzi LA. A perspective on the treatment of aphakic cystoid macular edema. Surv Ophthalmol. 1984;28 Suppl:540-53.

17. Photocoagulation for diabetic macular edema. Early Treatment Diabetic Retinopathy Study report number 1. Early Treatment Diabetic Retinopathy Study research group. Arch Ophthalmol. 1985;103(12):1796-806.

18. Neubauer AS, Priglinger S, Ullrich S, Bechmann M, Thiel MJ, Ulbig MW, et al. Comparison of foveal thickness measured with the retinal thickness analyzer and optical coherence tomography. Retina. 2001;21(6):596-601.

\section{1 de Outubro de 2006 Jurerê Beach Village Florianópolis - SC}

*Participação neste evento conta 4 pontos para a revalidação do título de especialista em oftalmologia

\section{INFORMAÇÕES}

Toll free: $0800-48110$

E-mail: reservahoteis@jurere.com.br Home page: www.cbe.org.br 